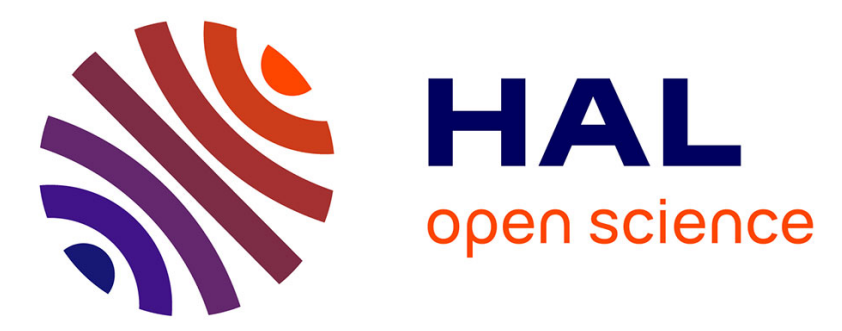

\title{
Treating critically ill anaemic patients with erythropoietin: why not?
}

Sigismond Lasocki, Antoine Kimmoun, Gerald Chanques, Lionel Velly, Frédéric Pène

\section{- To cite this version:}

Sigismond Lasocki, Antoine Kimmoun, Gerald Chanques, Lionel Velly, Frédéric Pène. Treating critically ill anaemic patients with erythropoietin: why not?. Intensive Care Medicine, 2020, 46 (9), pp.1794-1795. 10.1007/s00134-020-06175-3 . hal-02903241

\section{HAL Id: hal-02903241 \\ https://hal.science/hal-02903241}

Submitted on 29 Jul 2021

HAL is a multi-disciplinary open access archive for the deposit and dissemination of scientific research documents, whether they are published or not. The documents may come from teaching and research institutions in France or abroad, or from public or private research centers.
L'archive ouverte pluridisciplinaire $\mathbf{H A L}$, est destinée au dépôt et à la diffusion de documents scientifiques de niveau recherche, publiés ou non, émanant des établissements d'enseignement et de recherche français ou étrangers, des laboratoires publics ou privés. 


\title{
Treating critically ill anaemic patients with erythropoietin: why not?
}

\author{
Sigismond Lasocki ${ }^{*} \quad$ Antoine Kimmoun², Gerald Chanques ${ }^{3}$, Lionel Velly ${ }^{4,5}$ and Frédéric Pène ${ }^{6}$
}

\section{Dear Editor,}

We read with great interest the clinical practice guidelines on transfusion strategies recently published in the journal [1]. Although it followed a well designed and robust methodology, we are concerned by the recommendation against the use of erythropoietin (EPO, with or without iron) in critically ill patients. Following a similar methodology, we ended up with different conclusions in our national guidelines under the aegis of the French society of anaesthesiology and critical care (SFAR) and the French intensive care society (SRLF) $[2,3]$. Indeed, recent meta-analyses report a decrease in red blood cell transfusion and a reduction in mortality (relative risk for hospital mortality 0.82 , 95\% CI $0.71-0.94, p=0.006$, $I^{2}=0.1 \%$ ) [4], without evidence for increased morbidity, neither for thromboembolic events nor for cardiovascular complications $[4,5]$. This is why we recommended the use of erythropoietin to treat anaemia in the critically ill patients. Because the use of EPO is not widely admitted for critically ill patients and because morbidity is not well described in all the randomized controlled trials (RCTs), we choose to downgrade the recommendation to a grade 2 level (optional recommendation). We also mentioned that anaemic and trauma patients may draw a greater benefit from this treatment because the evidence of a reduction in mortality comes mainly from these subpopulations. We agree that one should remain cautious about the potential risk of adverse event (mainly thrombosis), and we also recommended to target reasonable haemoglobin levels (not higher than $12 \mathrm{~g} / \mathrm{dl}$ ), since higher targets are associated with worse outcomes

\footnotetext{
*Correspondence: sigismond@lasocki.com

1 Département Anesthésie Réanimation, Université d'Angers, CHU Angers,

4 rue Larrey, 49933 Angers Cedex 9, France
}

Table 1 Hospital cost for 40,000 UI of epoietin alpha and estimated cost for "one saved life"

\begin{tabular}{|c|c|c|}
\hline & Cost for $40,000 \mathrm{Ul}$ epoietin alpha ${ }^{\mathrm{a}}$ & $\begin{array}{l}\text { Estimated cost } \\
\text { for one life saved } \\
(\mathrm{KE})\end{array}$ \\
\hline Australia & $\begin{array}{l}\text { AUD } 965 \text { ( } € 588 \text { ) } \\
\text { (Cost for the patient: } \\
\text { AUD } 41 \text { or } 6.6=€ 25 \text { or } 4 \text { ) }\end{array}$ & 65.2 \\
\hline Canada & CDN $426(€ 296)$ & 32.8 \\
\hline Denmark & $€ 400$ & 44.4 \\
\hline France & $€ 61$ & 6.8 \\
\hline Germany & $€ 35$ & 3.9 \\
\hline Italy & $€ 120$ & 13.3 \\
\hline Spain & $€ 49$ & 5.4 \\
\hline UK & $£ 193(€ 222)$ & 11.3 \\
\hline USA & USD 685 (€ 632) & 70.1 \\
\hline Mean cost & $€ 267$ & 13.7 \\
\hline
\end{tabular}

in patients with chronic kidney disease [2, 3]. In addition, it has to be emphasized that iron deficiency was treated in most of the large RCTs evaluating erythropoietin, making it difficult to decipher the results of studies addressing the interest of erythropoietin alone or of erythropoietin + iron. The main reason advocate by the ESICM expert panel against the use of erythropoietin is the cost of the product [1]. Nowadays, due to the arrival of biosimilars in the market in most countries, costs of erythropoietin have dramatically decreased and the estimated "price" for saving one life is quite fair in most of the places, being as little as $3900 €$ in Germany (see Table 1). Efforts should probably be made at the European level to 
reduce the cost of erythropoietin where it remains high. We thus believe that erythropoietin should be considered to limit transfusion and improve outcome in critically ill patients. This is in agreement with the European Guidelines, indeed, the experts stated at the end of their argumentation that "At the same time, given the lack of signal for harm, some clinicians and ICUs may reasonably choose to adopt EPO, if sufficient resources exist for implementation" [1]. A new large randomized controlled trial is thus required to provide definite conclusions on the current benefit-risk balance of this treatment, in all ICU patients.

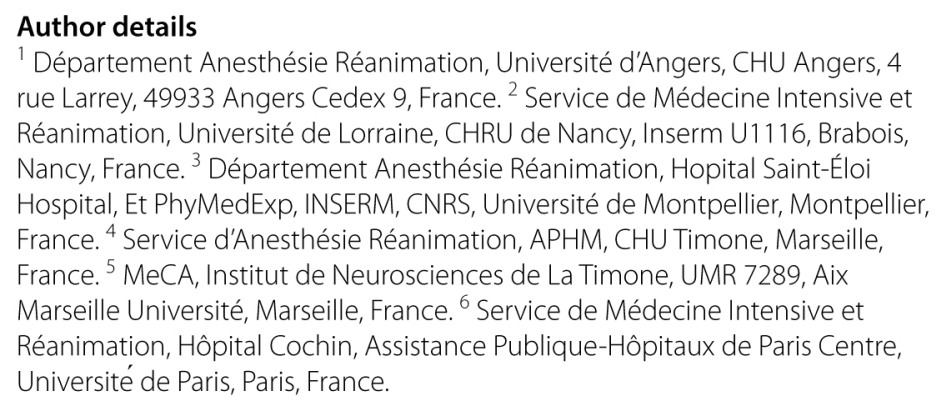

'Département Anesthésie Réanimation, Université d'Angers, CHU Angers, 4 rue Larrey, 49933 Angers Cedex 9, France. ${ }^{2}$ Service de Médecine Intensive et Réanimation, Université de Lorraine, CHRU de Nancy, Inserm U1116, Brabois, Nancy, France. ${ }^{3}$ Département Anesthésie Réanimation, Hopital Saint-Éloi Hospital, Et PhyMedExp, INSERM, CNRS, Université de Montpellier, Montpellier, France. ${ }^{4}$ Service d'Anesthésie Réanimation, APHM, CHU Timone, Marseille, France. ${ }^{5}$ MeCA, Institut de Neurosciences de La Timone, UMR 7289, Aix Marseille Université, Marseille, France. ${ }^{6}$ Service de Médecine Intensive et Réanimation, Hôpital Cochin, Assistance Publique-Hôpitaux de Paris Centre, Université de Paris, Paris, France.

\section{Compliance with ethical standards}

\section{Conflicts of interest}

SL: lecturer personally funded by Pfizer, Vifor Pharma, Masimo; consulting for Pfizer, Vifor Pharma; research support from Vifor Pharma; AK: lecturer personally funded by Aspen Medical France, Gilead, Baxter, MSD, Aguetant. GC: lecturer personally funded by Aspen Medical France, Orion Pharma; consulting for Orion Pharma. FP: consulting for Alexion Pharma (institutionally funded). LV declare no conflict of interest.

\section{References}

1. Vlaar AP, Oczkowski S, de Bruin S, Wijnberge M, Antonelli M, Aubron C, Aries P, Duranteau J, Juffermans NP, Meier J, Murphy GJ, Abbasciano R, Muller M, Shah A, Perner A, Rygaard S, Walsh TS, Guyatt G, Dionne JC, Cecconi M (2020) Transfusion strategies in non-bleeding critically ill adults: a clinical practice guideline from the European Society of Intensive Care Medicine. Intensive Care Med 46:673-696

2. Lasocki S, Pène F, Ait-Oufella H, Aubron C, Ausset S, Buffet $P$, Huet $O$, Launey $Y$, Legrand $M$, Lescot T, Mekontso Dessap A, Piagnerelli M, Quintard H, Velly L, Kimmoun A, Chanques G (2020) Management and prevention of anaemia (acute bleeding excluded) in adult critical care patients. Ann Intensive Care. https://doi.org/10.1186/s13613-020-00711-6

3. Lasocki S, Pène F, Ait-Oufella H, Aubron C, Ausset S, Buffet P, Huet O, Launey Y, Legrand M, Lescot T, Mekontso Dessap A, Piagnerelli M, Quintard H, Velly L, Kimmoun A, Chanques G (2020) Management and prevention of anaemia (acute bleeding excluded) in adult critical care patients. Anaesth Crit Care Pain Med. https://doi.org/10.1016/j.accpm.2020.04.004

4. Litton E, Latham P, Inman J, Luo J, Allan P (2019) Safety and efficacy of erythropoiesis-stimulating agents in critically ill patients admitted to the intensive care unit: a systematic review and meta-analysis. Intensive Care Med 45:1190-1199

5. Mesgarpour B, Heidinger BH, Roth D, Schmitz S, Walsh CD, Herkner H (2017) Harms of off-label erythropoiesis-stimulating agents for critically ill people. Cochrane Database Syst Rev (Online) 8:CD010969 